\title{
UNJUK KERJA PENERAPAN TEKNOLOGI VOIP PADA JARINGAN VPN (VIRTUAL PRIVATE NETWORK)
}

\author{
Oleh \\ Hadria Octavia *) \\ Jurusan Teknik Elektro, Politeknik Negeri Padang \\ Telp. 0751-72590 Fax. 0751-72576 Kampus Unand limau Manis Padang \\ ${ }^{*}$ Staf Pengajar Prodi Telekomunikasi Politeknik Negeri Padang
}

\begin{abstract}
VoIP (Voice over Internet Protocol) is a technology used for communication in the form of IP based voice media over long distances. The concept of a VPN (Virtual Private Network) in this paper makes a client that is on the public network can be connected to a LAN network. To use the VoIP server in the Linux operating system Trixbox, whereas for the VPN server using ClearOS and $X$-lite is used as a softphone to make calls to the client. Of testing at 64kbps bandwidth using the G711 codec produces value performance (delay, jitter, and packet loss) is not good, so that voice data delivered is less clear. Thus the choice of bandwidth for the G.711 codec 512kbps up is the best solution to get the value of the performance (delay, jitter, and packet loss) better. And a choice of 3 Greed (low, medium, high) on setting bandwidth, high is the best option. Because it can produce the best performance for VoIP VPN technology.
\end{abstract}

Keywords : VoIP, Trixbox, VPN, ClearOS, delay, jitter and paket loss.

\section{PENDAHULUAN}

Seiring dengan berkembangnya ilmu pengetahuan dan teknologi khususnya dalam bidang telekomunikasi, maka hampir semua sektor kehidupan manusia tidak dapat terpisahkan dari penggunaan teknologi tersebut, terutama alat komunikasi. Teknologi VoIP (Voice over Internet Protocol) adalah salah satu pilihan yang digunakan untuk berkomunikasi dalam bentuk media suara secara murah melalui portokol jaringan internet walaupun dengan jarak yang jauh.

$$
\text { VoIP (Voice over Internet }
$$

Protocol) adalah teknologi yang memungkinkan percakapan suara jarak jauh berbasis IP (Internet Protocol). Pada teknologi ini suara dirubah menjadi kode digital sebelum ditransmisikan ke jaringan paket-paket data, bukan sirkuit analog telepon biasa.

Dengan berkembangnya layanan voice ini bukan berarti bahwa tidak akan ada masalah yang muncul di masa yang akan datang. Salah satu kelemahan jaringan internet adalah bahwa data yang terkirim tidak terjamin kerahasiaannya sehingga siapapun dapat menangkap dan memanipulasi data tersebut.

Kebocoran informasi sering terjadi pada sebuah jaringan apalagi jaringan berbasis IP (Internet Protocol), sehingga siapapun bisa mencuri informasi tersebut, yang dapat merugikan berbagai pihak. VPN (Virtual Private Network) merupakan satu metoda yang handal dalam menangani masalah keamanan jaringan, terutama untuk pengiriman data 
penting baik itu berupa suara, gambar ataupun video.

\section{PERMASALAHAN}

Permasalahan yang dihadapi dalam pembuatan tugas akhir ini adalah bagaimana merancang sebuah layanan VoIP (Voice over Internet Protocol) pada VPN (Virtual Private Network). Pada sistem tersebut akan dianalisa performansinya yang meliputi delay (ms), packet loss (\%), dan jitter (ms).

\section{TEORI DASAR}

\subsection{Pengertian VoIP (Voice over Internet Protocol)}

VoIP (Voice over Internet Protocol) adalah teknologi yang mampu melewatkan data berupa trafik suara, dalam bentuk paket melalui jaringan IP (Internet Protokol). Jaringan IP merupakan jaringan komunikasi data yang berbasis packet-switch. Terdapat beberapa pengertian VoIP diantaranya :

1. VoIP (Voice over Internet Protocol) dikenal juga dengan sebutan IP Telephony didefinisikan sebagai suatu sistem yang menggunakan jaringan internet untuk mengirimkan data paket suara dari suatu tempat ke tempat yang lain menggunakan perantara protokol IP (Tharom, 2002).

2. VoIP adalah teknologi yang memanfaatkan Internet Protocol untuk menyediakan komunikasi voice secara elektronis dan real-time. (Raharja, Anton., 2006).

\subsubsection{Kualitas VoIP}

Kualitas layanan VoIP (Voice over Internet Protocol) atau yang biasa disebut QoS (Quality of Service) adalah metodemetode yang bisa digunakan pada jaringan IP untuk melayani suatu layanan aplikasi tertentu. Beberapa parameter yang mempengaruhi QoS antara lain:

1. Pemenuhan kebutuhan bandwidth

2. Keterlambatan data(latency)

3. Packet loss dan desequencing
4. Jenis kompresi data

5. Interopabilitas peralatan(vendor yang berbeda)

6. Jenis standar multimedia yang digunakan (H.323/SIP/MGCP).

\subsubsection{SIP (Session Innitiation Protocol)}

SIP (Session Innitiation Protocol) merupakan protokol pensiyalan untuk mengatur, memulai dan mengakhiri sesi video dan suara yang ada dalam jaringan paket data pada layer aplikasi. Jaringan SIP dibangun dari empat bagian SIP, keempat bagian tersebut memiliki fungsi-fungsi khusus dan dalam komunikasi SIP, keempat bagian tersebut yaitu ;

1. User Agent (UA) - End User

a. User Agent Client (UAC) : bagian ini terdapat pada pemakai (client), yang digunakan untuk melakukan inisiasi request dari server SIP ke UAS

b. User Agent Server (UAS) : bagian ini berfungsi untuk mendengar dan merespon terhadap request SIP

2. Proxy Server - Gerbang menuju jaringan SIP

Server ini menerima request SIP dan meneruskan ke server yang dituju yang memiliki informasi tentang user yang dipanggil.

3. Redirect Server - Memetakan lokasi user dan meneruskan permintaan

Server ini setelah menerima request SIP, menentukan server yang dituju selanjutnya dan mengembalikan alamat server yang dituju selanjutnya kepada client daripada meneruskan request ke server yang dituju tersebut.

4. Register Server - Memproses registrasi user.

Server ini menerima request registrasi dari user SIP dan melakukan update terhadap lokasi user dengan server ini. 


\subsection{Layanan Penerapan Teknologi VoIP}

Seperti penjelasan sebelumnya, VoIP (Voice over Internet Protocol) merupakan salah satu bagian dari teknologi transmisi untuk mentransmisikan komunikasi suara melalui IP, seperti internet ataupun packet switched networks. Dengan menggunakan VoIP, kita dapat melakukan panggilan telepon melalui koneksi internet, tidak lagi menggunakan saluran telepon konvensional yang melakukan transmisi secara analog.

VoIP mengkonversikan atau mengubah suara (data) yang merupakan sinyal analog menjadi sinyal digital yang ditransmisikan melalui internet. Tidak seperti telepon konvensional yang mentransmisikan suara anda menggunakan sinyal listrik melalui kabel. Secara garis besar layanan VoIP dapat dibagi menjadi empat, yaitu ;

\subsubsection{Komunikasi komputer ke komputer VoIP}

Layanan ini merupakan layanan voice call yang menggunakan komputer sebagai alat komunikasi. Dengan menggunakan layanan khusus di internet kita bisa menggunakan komputer kita yang telah terhubung dengan internet untuk melakukan panggilan ke komputer lain yang menggunakan layanan yang sama.

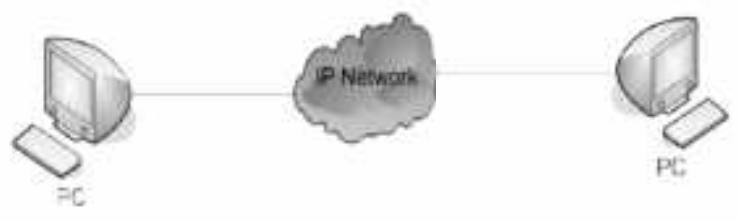

\section{Gambar 1. Hubungan dari Komputer ke Komputer}

Banyak penyedia layanan VoIP di internet. Salah satu layanan yang mendukung panggilan suara melalui internet adalah Yahoo messenger. Dengan menggunakan Yahoo messenger kita bisa melakukan voice call dengan sesama user. Layanan VoIP komputer ke komputer dapat dilakukan secara gratis, anda hanya cukup menyediakan koneksi internet pada komputer anda.

\subsubsection{Komunikasi komputer ke telepon VoIP}

Layanan ini merupakan layanan yang memungkinkan kita melakukan panggilan dari komputer ke telepon, baik itu telepon tetap atau mobile phone (handphone) bahkan nomor internasional di seluruh dunia. Layanan ini juga membutuhkan penyedia layanan di internet, seperti Skype.

Lain halnya dengan layanan komputer ke komputer VoIP, layanan ini membutuhkan biaya yang harus dibeli terlebih dahulu (sistem prabayar). Cara menggunakan layanan ini tidak terlalu sulit.

Pertama, kita harus memiliki account di penyedia layanan terkait, biasanya membuat account tidak di pungut biaya. Lalu kita membeli kredit atau bisa juga disebut pulsa, yang akan digunakan untuk melakukan panggilan ke telepon.

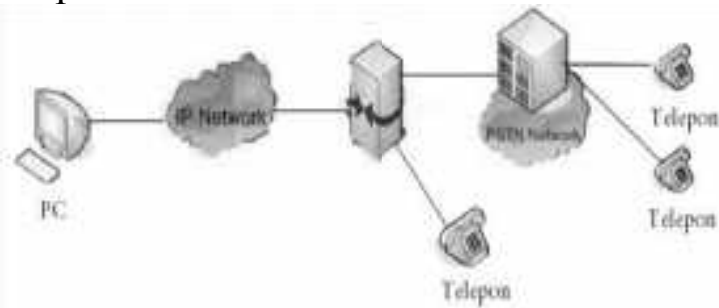

Gambar 2. Komunikasi Komputer ke Telepon

\subsubsection{Komunikasi telepon ke komputer VoIP}

Layanan VoIP call ini merupakan layanan yang memungkinkan anda melakukan panggilan dari telepon ke komputer. Sama halnya dengan layanan komputer ke telepon VoIP, skype juga menyediakan layanan ini. 


\subsubsection{Komunikasi telepon ke telepon VoIP}

Layanan ini dilakukan dengan menggunakan pesawat telepon khusus atau telepon konvensional yang di hubungkan dengan VoIP adapter. Untuk menggunakan layanan ini kita harus menggunakan penyedia layanan telepon ke telepon VoIP, seperti Phone Power. Dengan layanan ini kita dapat melakukan panggilan kemana pun diseluruh dunia yang menggunakan alat yang mendukung.

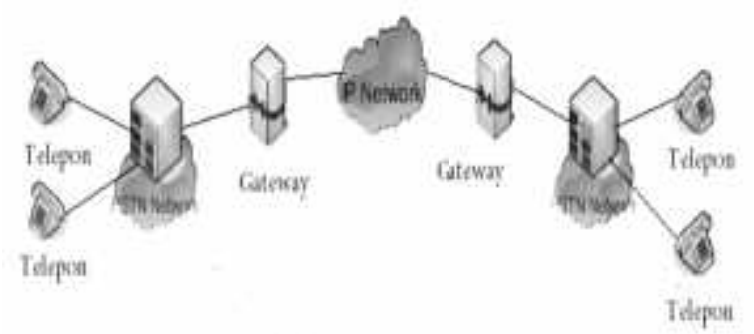

Gambar 3. Komunikasi Telepon ke Telepon

\subsection{Pengertian VPN (Virtual Private Network) \\ VPN (Virtual Private Network)}

adalah suatu jaringan privat (biasanya untuk instansi atau kelompok tertentu) di dalam jaringan internet (publik),dimana jaringan privat ini seolah-olah sedang mengakses jaringan lokalnya tapi menggunakan jaringan publik

VPN merupakan salah satu teknik pengamanan jaringan dengan cara membuat suatu tunnel, misalkan pada jaringan publik atau internet sehingga bersifat private dan aman. VPN dikatakan bersifat private karena ketika akan dibutuhkan sebuah koneksi VPN membutuhkan authentikasi untuk memastikan bahwa kedua ujung dalam koneksi adalah user yang sesuai dengan yang diberikan kewenangan untuk mengakses suatu user.

Meningkatnya prevalensi koneksi internet broadband ke kantor dan rumah yang letaknya jauh membuat akses yang lebih murah ke internet menjadi hal yang menarik. VPN memungkinkan masing- masing remote user dari jaringan dapat berkomunikasi dalam jalur yang aman dan dapat diandalkan dengan menggunakan internet sebagai perantara untuk terkoneksi ke LAN (Local Area Network) pribadi Anda. VPN dapat dikembangkan untuk mengakomodasi lebih banyak pengguna dan tempat-tempat lain secara lebih mudah.

\section{Tunneling}

Tunneling merupakan metode untuk transfer data dari satu jaringan ke jaringan lain dengan memanfaatkan jaringan internet secara terselubung. Disebut tunnel atau saluran karena aplikasi yang memanfaatkan hanya melihat dua end point atau ujung, sehingga paket yang lewat pada tunnel hanya akan melakukan satu kali lompatan. Data yang akan ditransfer dapat berupa frame (paket) dari protokol yang lain.

Protokol tunneling tidak mengirimkan frame sebagaimana yang dihasilkan oleh node asalnya begitu saja melainkan membungkusnya (mengenkapsulasi) dalam header tambahan. Header tambahan tersebut berisi informasi routing sehingga data (frame) yang dikirim dapat melewati jaringan internet. Jalur yang dilewati data dalam internet disebut tunnel. Saat data tiba pada jaringan tujuan, proses yang terjadi selanjutnya adalah dekapsulasi, kemudian data original akan dikirim ke penerima terakhir. Tunneling mencakup secara keseluruhan mulai dari enkapsulasi, transmisi dan dekapsulasi.

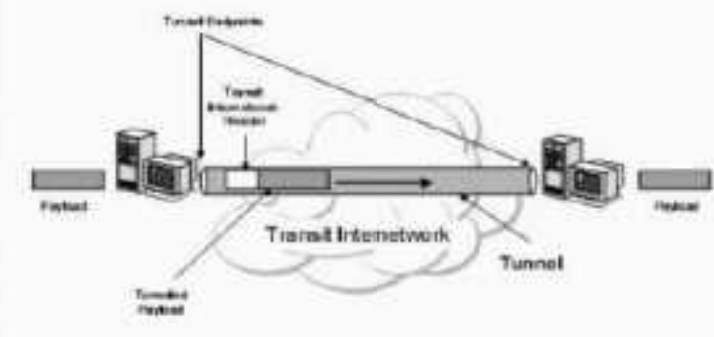

Gambar 4. Proses Tunneling pada VPN 


\subsection{Performansi Layanan VoIP}

Untuk mendapatkan hasil QoS (Quality of Service) yang optimal tidak diperoleh langsung dari infrastruktur yang ada, melainkan diperoleh langsung dengan mengimplementasikannya pada jaringan bersangkutan. Beberapa parameter yang mempengaruhi QoS (Quality of Service) diantaranya ;

\subsubsection{Delay}

Delay adalah Interval waktu saat suara mulai dikirimkan oleh pemanggil menuju penerima panggilan yang disebabkan salah satunya oleh konversi suara analog menjadi data-data digital.

Delay merupakan faktor yang penting dalam menentukan kualitas VoIP. Semakin besar delay yang terjadi maka akan semakin rendah kualitas VoIP yang dihasilkan. Besarnya delay maksimum yang direkomendasikan oleh ITU untuk aplikasi voice adalah $150 \mathrm{~ms}$, sedangkan delay maksimum dengan kualitas suara yang masih dapat diterima user adalah $250 \mathrm{~ms}$.

Delay end-to-end adalah jumlah delay koversi suara analog-digital, delay waktu paketisasi atau bisa juga disebut delay panjang paket dan delay jaringan saat $\mathrm{t}$ (waktu).

\subsubsection{Jitter}

Jitter merupakan variasi delay yang terjadi akibat adanya selisih waktu atau interval antar kedatangan paket di penerima. Untuk mengatasi jitter maka paket data yang datang dikumpulkan dulu dalam jitter buffer selama waktu yang telah ditentukan sampai paket dapat diterima pada sisi penerima dengan urutan yang benar.

Selain itu alternatif solusi permasalahan di atas adalah membangun link antar node pada jaringan dengan spesifikasi dan dimensi dengan QoS (Quality of Servis) yang baik dan dapat mengantisipasi perubahan lonjakan trafik hingga pada suatu batas tertentu.

\subsubsection{Packet Loss}

Packet loss (kehilangan paket) terjadi ketika peak load dan congestion (kemacetan transmisi paket akibat padatnya traffic yang harus dilayani) dalam batas waktu tertentu, maka frame (gabungan data payload dan header yang di transmisikan) suara akan dibuang sebagaimana perlakuan terhadap frame data lainnya pada jaringan berbasis IP.

Salah satu alternatif solusi permasalahan di atas adalah membangun link antar node pada jaringan VoIP dengan spesifikasi dan dimensi dengan QoS (Quality of Servis) yang baik dan dapat mengantisipasi perubahan lonjakan trafik hingga pada suatu batas tertentu.

Aplikasi VoIP merupakan aplikasi real time, sehingga tidak dapat mentolerir delay (dalam batasan tertentu) dan packet loss. Delay dapat diminimalkan dengan menggunakan teknologi packet switching sebagai pengganti data switching. Cara lain yang dapat ditempuh adalah mengoptimalkan penggunaan bandwidth, mengatur metode antrian yang dipakai dan menggunakan protokol-protokol managemen untuk mengatur paket data yang dilewatkan.

\section{PERANCANGAN SISTEM}

\subsection{Spesifikasi dan Perancangan Sistem}

Pada bab ini akan di jelaskan lebih rinci mengenai spesifikasi dan perancangan sistem yang akan di bangun. Baik itu dari tools yang digunakan, input yang di masukkan dan output yang di inginkan. Perancangan sistem VoIP pada VPN ini mencakup penggunaan hardware, tools (software) yang digunakan, serta topologi pemodelan sistem yang akan di lakukan.

\subsubsection{Kebutuhan Hardware}

Dalam pembuatan tugas akhir ini sistem yang ingin dibangun berupa suatu jaringan komputer dengan menggunakan:

1. Komputer 5 unit yang berfungsi sebagai: 
a. VoIP server 1 unit

b. VPN server 1 unit

c. VoIP client 3 unit

2. Hub 1 buah

3. Modem 1 buah

4. Ethernet card 2 buah

5. Kabel UTP tipe 5 dengan RJ-45 secukupnya

\subsubsection{Kebutuhan Software}

Adapun software yang digunakan untuk merealisasikan sistem pada tugas akhir ini adalah sebagai berikut;

\subsubsection{Linux Tribox CE}

Linux Trixbox CE (Community Edition) adalah sebuah VoIP phone sistem yang mudah diinstalasi, memanfaatkan software Asterisk PBX sebagai basis. Trixbox dapat dikonfigurasi untuk menangani mulai dari satu sambungan telepon pribadi, puluhan atau ratusan sambungan telepon untuk perkantoran, dapat disambungkan ke beberapa saluran T1 di sebuah call center yang menghandle jutaan menit percakapan per bulan. Sebuah web GUI (web based) memungkinkan konfigurasi dan pengoperasian menjadi mudah.

\subsubsection{ClearOS}

ClearOs adalah sistem operasi berbasis linux yang dikhususkan pengunaannya sebagai sebuah server. Namun maskipun berbasis linux, clearos sangat mudah digunakan bahkan oleh orang yang belum mengenal linux sekalipun. Karena sistem konfigurasinya yang berbasis Web GUI.

\subsubsection{X-Lite}

$\mathrm{X}$-Lite merupakan softphone yang berfungsi sebagai user agen Client dan User agent server pada protokol SIP.X-lite digunakan karena memiliki beberapa kelebihan. Selain mendukung protokol SIP dan H323, Xlite juga mendukung berbagai jenis kompresi Codec, video conference, metode keamanan SRTP dan TLS.

\subsubsection{Wireshark}

Wireshark adalah salah satu tools terbaik yang biasa di gunakan untuk menganalisa sebuah paket jaringan, atau biasa disebut network packet analyzer. Network packet analyzer akan mencoba menangkap paket-paket jaringan dan berusaha untuk menampilkan sebuah informasi di paket tersebut sedetail mungkin.

\subsection{Pemodelan Sistem}

Pada tugas akhir ini akan diimplementasikan layanan VoIP pada VPN (Virtual Private Network). Topologi jaringan pemodelan sistem yang digunakan seperti yang terlihat pada gambar dibawah ini.

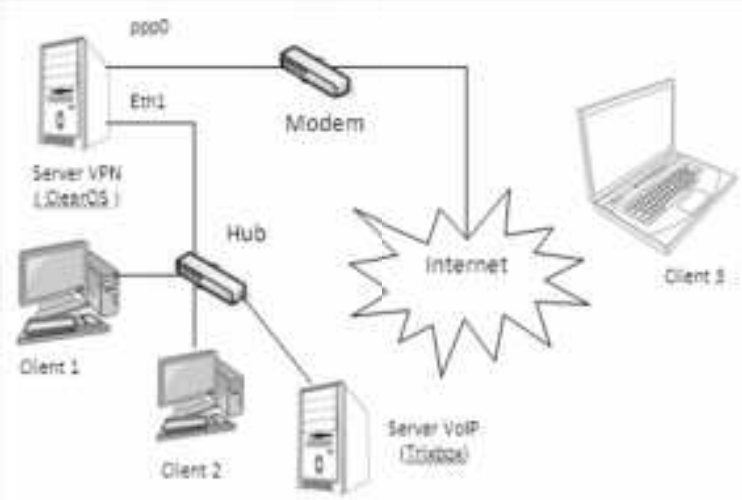

Gambar 5. Topologi Pemodelan Sistem

Pada gambar 5. dapat dilihat bahwasanya client 1 dan client 2 terhubung pada sebuah hub yang di dalamnya juga terdapat server VoIP dan server VPN. Server VPN berada pada eth1 sedangkan untuk ppp0 pada modem yang menghubungkan antara jaringan LAN ke jaringan publik. Dan untuk client 3 terhubung pada internet (jaringan publik) yang nantinya akan di jembatani oleh VPN. Proses tunneling terjadi pada client 3 , sehingga nantinya clinet 3 seakan 
berada pada jaringan LAN yang disana terdapat client 1 dan client 2 .

Tabel 1. Spesifikasi perangkat system

\begin{tabular}{|c|c|c|c|}
\hline & $\begin{array}{l}\text { Server } \\
\text { VoIP }\end{array}$ & Server VPN & Client \\
\hline $\begin{array}{l}\text { IP } \\
\text { address }\end{array}$ & 102.168 .0 .17 & $\begin{array}{l}\text { Pppo:110.137.90.134 } \\
\text { ethil 192.165.0.1 }\end{array}$ & $\begin{array}{l}192.1580 .8- \\
20\end{array}$ \\
\hline $\begin{array}{l}\text { Operasi } \\
\text { Sisten }\end{array}$ & $\begin{array}{l}\text { Trixbox } \\
2.60\end{array}$ & Clearos 52 & Windows XP \\
\hline Hardisk: & $320 \mathrm{~GB}$ & $320 \mathrm{~GB}$ & $320 \mathrm{~GB}$ \\
\hline Nemori & $1 \mathrm{~GB}$ & $1 \mathrm{~GB}$ & $1 \mathrm{~GB}$ \\
\hline Prosesor & $\begin{array}{l}\text { Intel } \\
\text { Pestum } \\
\text { Dial Ccre }\end{array}$ & $\begin{array}{l}\text { Intel Pentium Dual } \\
\text { Core }\end{array}$ & $\begin{array}{l}\text { Intel Pentium } \\
\text { Dral Core }\end{array}$ \\
\hline
\end{tabular}

\section{a. Perancangan pada sisi server}

VoIP (Voice over Internet

Protocol) server menggunakan sistem operasi linux. Penggunaan linux disini menggunakan distributor (distro) trixbox, yang khusus digunakan untuk menangani VoIP.

Sedangkan untuk server VPN (Virtual Private Network) menggunakan sistem operasi ClearOS yang di kostumasi khusus untuk keperluan server.

Proses pertama yang dilakukan dalam perancangan server adalah instalasi Trixbox versi 2.6.0.5 pada PC yang digunakan untuk server VoIP . Kemudian dilanjutkan dengan instalasi ClearOS 5.2. sebagai server VPN.

Setelah kedua server di instal, dilakukan konfigurasi pada kedua server dengan pembuatan akun agar VPN pada VoIP dapat melakukan komunikasi dengan client yang berada pada LAN, dan client yang berada pada jaringan public yang mempunyai akun pada server VPN terlebih dahulu.

\section{b. Perancangan pada sisi client}

Perancangan pada sisi client dengan menyiapkan PC yang mampu menerima dan melakukan panggilan. Tahap perancangan ini dilakukan dengan instalasi X-lite (softphone) pada masingmasing client. Kemudian mengaktifkan softphone untuk melakukan registrasi ke server VoIP.

Registrasi ke server VoIP dilakukan dengan mengkonfigurasi IP address yang disesuaikan dengan IP address pada server. Selanjutnya menambahkan akun pada server VPN, karena seperti yang diketahui VPN merupakan sebuah koneksi virtual yang bersifat private, sehingga tidak semua orang bisa terkoneksi ke jaringan ini dan mengaksesnya kecuali mereka yang terdaftar pada server VPN tersebut.

\section{c. Perancangan pengujian}

Perancangan pengujian dilakukan dengan beberapa tahap, yakni pengujian koneksi antara server dan client, serta pengujian koneksi antara masing-masing client dengan cara mengetikan perintah "ping alamat IP" pada command prompt.

Setelah semua sistem dipastikan terkoneksi dengan baik, selanjutnya dilakukan panggilan antara client yang berada pada jaringan LAN. Setelah terjadi komunikasi lalu ditangkap beberapa paket data untuk dianalisa nilai delay, jitter, dan packet loss dengan menggunakan wireshark, seperti yang terlihat pada gambar 3. Pengujian berikutnya seperti tampilan gambar 4. Sama halnya dengan panggilan sebelumnya, namun panggilan ini sudah diamankan dengan adanya akun VPN yang dimiliki client 3 yang tidak terhubung dengan jaringan LAN.

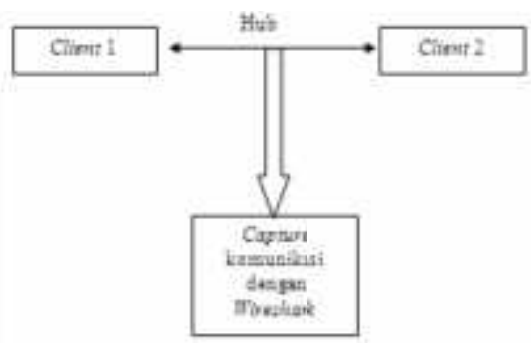
Gambar 6. Blok Diagram panggilan
VoIP tanpa VPN 


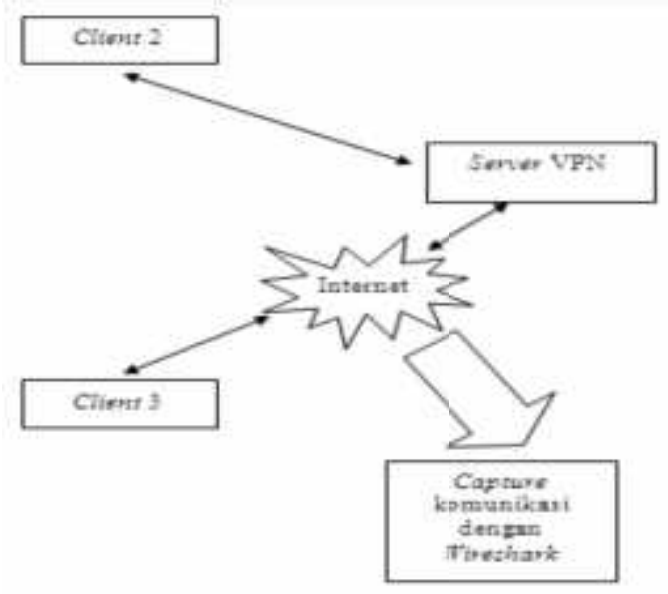

Gambar 7. Blok Diagram Panggilan VoIP menggunakan VPN

\subsection{Implementasi Sistem}

Untuk memudahkan pembuatan dan analisis sitem maka dibuat suatu flowchart kerja sistem sebagai berikut.

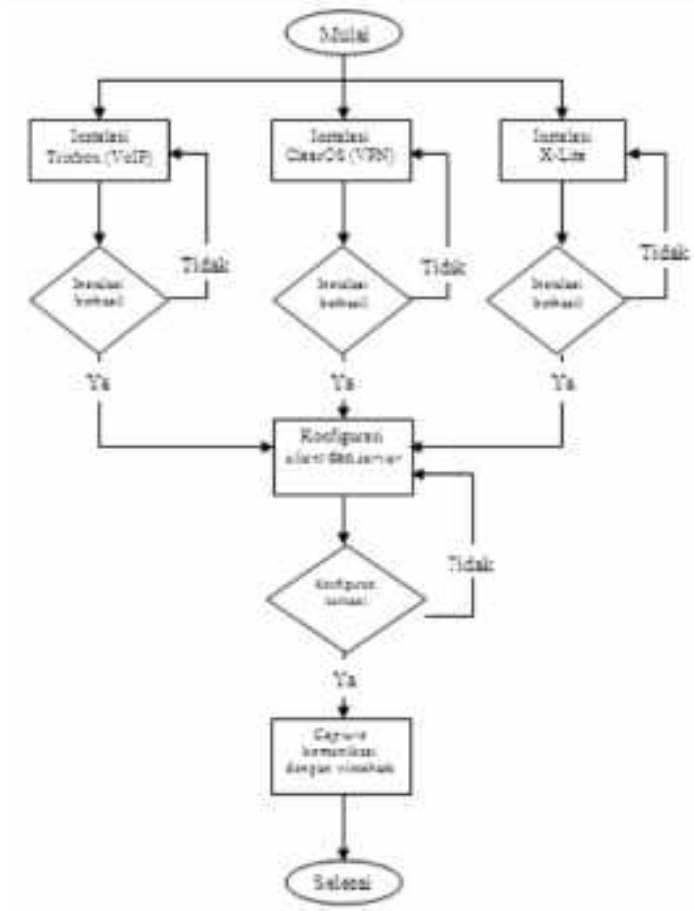

\section{Gambar 8. Flowchart Sistem}

\section{PENGUJIAN DAN ANALISA}

\subsection{Pengujian sistem}

Pengujian sistem dilakukan untuk mengetahui apakah sistem yang sudah dipasang terhubung kesemua perangkat yang digunakan. Maka dari itu kita perlu melakukan pengujian terhadap interface network untuk mengetahui apakah jaringan / sistem dapat melewatkan paketpaket data dan berjalan dengan baik dengan menjalankan perintah ping di command prompt pada semua computer, dan jika terhubung akan terlihat seperti gambar 9 .

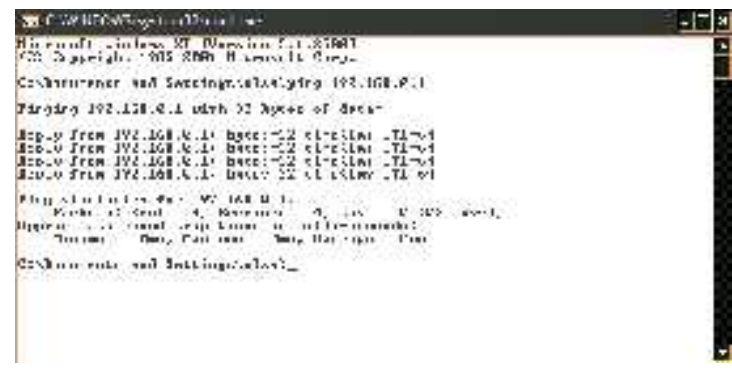

\section{Gambar 9. Pengujian interface network}

Untuk topologi sistem yang digunakan pada tugas akhir ini adalah topologi star, seperti pada gambar 5. Kelebihan dari topologi star yakni tidak langsung terhubung satu sama lain tetapi melalui perangkat pusat pengendali yang disebut HUB. Kabel yang di butuhkan hanya sebanyak computer dalam jaringan. Memiliki sifat robustness yaitu jika ada link rusak maka tidak akan berpengaruh pada link yang lain.

\subsection{Pengujian pada sisi server}

Tujuan pengujian pada sisi server adalah untuk mengetahui server VoIP (Voice over Internet Protocol) dapat menerima dan melakukan panggilan antar client serta server VPN (Virtual Private Network) dapat mengakses dan berkomunikasi dengan client yang terhubung pada LAN (Local Area Network). Untuk mengetahui server bekerja dengan baik, ada beberapa tahapan yang harus dilalui, yaitu :

1. Komputer server VoIP booting secara normal sampai proses berakhir ditandai dengan munculnya halaman login user pada layar monitor seperti pada gambar 10 . 
Velcoes to trixbox of

Por access to the trixbox web foll use this URt stif Http://192.169, e.17

Por belp on trixdox cousunds you cas esit froe this comend stell tyge help-trixdox.

trixtoxd login: root

Passuerl: .

\section{Gambar 10. Halaman Login user trixbox}

2. Komputer server VoIP dapat dikonfigurasi melalui remote web base sampai ke tahap halaman login user seperti pada gambar 11. Pada gambar 11 diminta untuk login dengan cara mengetikkan "maint" pada user name, dan "password" pada password.

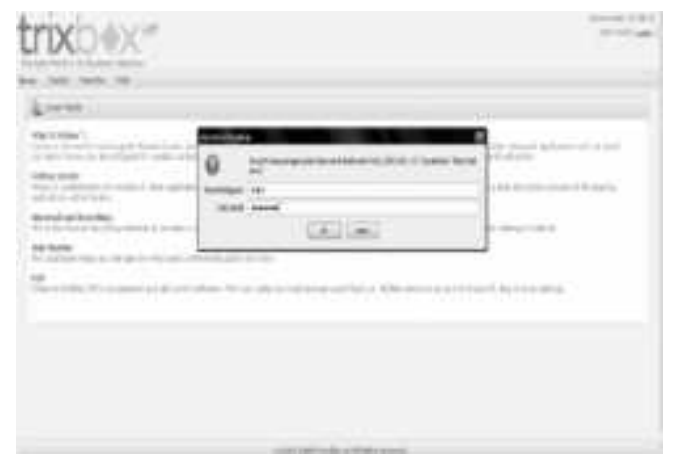

Gambar 11. Halaman Login user pada web browser server VoIP

3. Komputer server VPN booting secara normal sampai proses berakhir ditandai dengan munculnya halaman login user pada layar monitor seperti pada gambar 5.4.

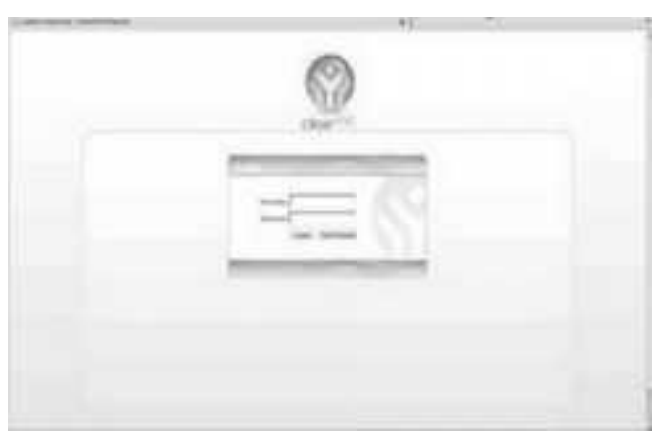

\section{Gambar 12. Tampilan login user VPN server}

Pada gambar 12 diminta untuk login dengan cara mengetikkan "root" pada user name, dan password yang sama dengan penyetingan sebelumnya.

\subsection{Pengukuran dan Analisis performansi VoIP \\ Pengukuran dan analisis} performansi VoIP (Voice over Internet Protocol) pada VPN (Virtual Private Network) meliputi delay, jitter, dan packet loss. Hasil pengukuran yang didapat akan dibandingkan antara layanan VoIP tanpa menggunakan VPN, dan yang menggunakan VPN dengan rekomendasi ITU-T untuk layanan voice, mengenai standart ITU-T untuk kualitas layanan VoIP adalah sebagai berikut:

1. Delay (harus $<150 \mathrm{~ms}$, ITU-T G.114)

2. Jitter (harus $<75 \mathrm{~ms}$, ITU-T Y.1541)

3. Packet loss $(<5 \%$, ITU-T Y.1541)

Pengukuran dilakukan dengan berbagai variasi bandwidth yang digunakan. Pembagian Bandwidth dilakukan pada ClearOS yang juga digunakan sebagai server VPN (Virtual Private Network) dengan cara memilih "Gateway" kemudian pilih "Bandwith" pada bagian "Bandwith and QoS" seperti tampilan pada gambar 13 . 


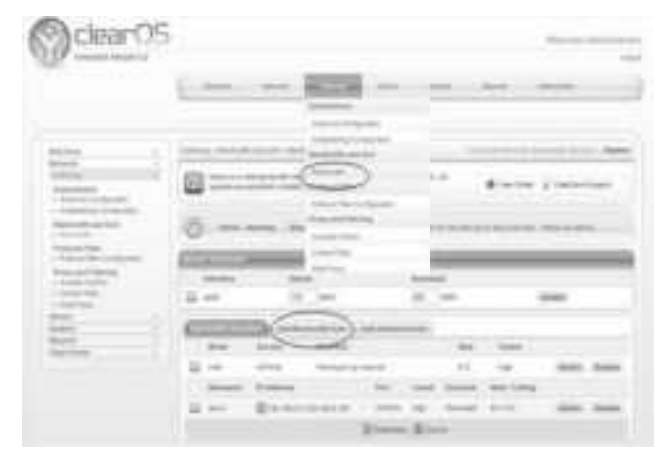

Gambar 13. Pembagian Bandwith

\subsubsection{Pengukuran dan analisis VoIP tanpa VPN}

Bandwidth yang digunakan sebagai pengukuran diambil dari nilai 64 kbps, 128 kbps, 256 kbps, hingga 512 kbps. Pengambilan data dilakukan sebanyak 4 kali panggilan. Untuk pengukuran nilai performansinya dilakukan dengan software wireshark, dengan menangkap paket-paket data RTP (Real Time Protocol) yang melewati jaringan tersebut.

Dari tabel 2 dapat dilihat bahwasanya nilai delay yang di dapatkan masih dapat diterima sesuai referensi ITUT G.114, yakni kurang dari $150 \mathrm{~ms}$.

Table 2. Tabel nilai performansi VoIP tanpa VPN

\begin{tabular}{|c|c|c|c|c|}
\hline $\begin{array}{c}\text { Co } \\
\text { dec }\end{array}$ & $\begin{array}{c}\text { Bandwidth } \\
\text { Kbps }\end{array}$ & $\begin{array}{c}\text { Delay } \\
\text { (ms) }\end{array}$ & $\begin{array}{c}\text { Jitter } \\
\text { (ms) }\end{array}$ & $\begin{array}{c}\text { Packet } \\
\text { Loss } \\
(\%)\end{array}$ \\
\hline \multirow{3}{*}{ G711 } & 64 & 40,10 & 18,03 & 0,9 \\
\cline { 2 - 5 } & 128 & 37,92 & 7,64 & 0,1 \\
\cline { 2 - 5 } & 256 & 30,24 & 4,58 & 0 \\
\cline { 2 - 5 } & 512 & 23,76 & 2,94 & 0 \\
\hline
\end{tabular}

Parameter lain yang dianalisa adalah jitter untuk mengetahui delay kedatangan antar satu paket dengan paket lainnya. Semakin besar jitter maka semakin besar perbedaan waktu antara suara asli dengan suara yang terdengar.

Jitter sangat mempengaruhi kualitas suara. Semakin besar jitter maka suara yang dihasilkan akan semakin tidak jelas (terputus-putus). Nilai jitter berpengaruh ketika paket RTP yang datang akan di proses menjadi suara. Ketika nilai jitter lebih kecil dari waktu pemrosesan paket data, maka sebelum paket selesai di proses paket selanjutnya telah datang untuk menunggu diproses. Sehingga suara yang dihasikan pun bagus. Ketika jitter dari paket jauh lebih besar dari buffer jitter, maka kualitas suara akan menjadi buruk. Hal ini terjadi ketika menggunakan bandwidth 64 pada codec G711.

Packet loss menentukan besarnya paket yang hilang di dalam perjalanannya dari source address ke destination address. Semakin besar packet loss menyebabkan suara yang dikirim tidak akan bisa didengarkan (hilang). Sesuai dengan tabel 5.1. nilai Packet Loss untuk bandwidth 64 kbps rata-rata hampir mencapai 1\% maka pada bandwidth 64 Kbps terdapat beberapa paket yang tidak sampai ke penerima sehingga kualitas pembicaraan menjadi tidak layak. Sedangkan nilai Packet Loss pada bandwidth $128 \mathrm{Kbps}$ dan seterusnya mempunyai nilai $0,1 \%$ bahkan hingga mencapai $0 \%$ yang berarti baik/layak untuk pembicaraan.

\subsubsection{Pengukuran dan analisis layanan VoIP menggunakan VPN}

Sama halnya dengan pengukuran sebelumnya, untuk pengukuran dan analisis layanan VoIP menggunakan VPN juga dilakukan dengan 4 variasi bandwith yang berbeda yakni 64kbps, 128kbps, $256 \mathrm{kbps}$, dan $512 \mathrm{kbps}$ dengan codec G.711.

Table 3. Tabel nilai performansi VoIP dengan VPN

\begin{tabular}{|c|c|c|c|c|}
\hline Conder & $\begin{array}{c}\text { Bandwidth } \\
\text { Klyps }\end{array}$ & $\begin{array}{l}\text { Delav } \\
\text { (ms) }\end{array}$ & $\begin{array}{l}\text { Tirrer } \\
\text { (ms) }\end{array}$ & $\begin{array}{c}\text { Parket } \\
\text { Toss } \\
(0 \text { u })\end{array}$ \\
\hline \multirow[t]{4}{*}{ G711 } & $6+$ & $\begin{array}{c}108,2 \\
I\end{array}$ & 10,01 & 01 \\
\hline & 126 & 30,01 & 1,52 & 0 \\
\hline & 236 & 3182 & 3,49 & 0 \\
\hline & 512 & 25.76 & $30 !$ & 0 \\
\hline
\end{tabular}


Dari tabel 3 nilai jitter yang didapatkan untuk VoIP menggunakan VPN tidak terlalu tinggi yakni $10,01 \mathrm{~ms}$ untuk bandwith $64 \mathrm{kbps}, 7,52 \mathrm{~ms}$ untuk bandwith $128 \mathrm{kbps}, 5,49 \mathrm{~ms}$ untuk bandwith $256 \mathrm{kbps}$, dan 3,01 ms untuk bandwith $512 \mathrm{kbps}$ serta masih sesuai dengan rekomendasi dari ITU-T Y.1541 serta tidak jauh berbeda dengan nilai jitter VoIP tanpa VPN.

Tabel 4. Tabel perbandingan performansi VoIP tanpa dan dengan VPN

\begin{tabular}{|c|c|c|c|c|c|c|}
\hline \multirow[t]{2}{*}{ Codec } & \multirow[t]{2}{*}{$\mathrm{G} 711$} & \multicolumn{4}{|c|}{ Dandwath } & \multirow{2}{*}{$\begin{array}{l}\text { Standa } \\
\text { 1I U-1 }\end{array}$} \\
\hline & & $\begin{array}{c}84 \\
\text { Etp. }\end{array}$ & $\begin{array}{l}128 \\
\text { stps }\end{array}$ & $\begin{array}{l}246 \\
\text { boys }\end{array}$ & $\begin{array}{l}\text { S11 } \\
\text { Lbpy }\end{array}$ & \\
\hline '1 tepa & \multirow{4}{*}{ Delay } & 40,20 & $3+2,2$ & $30: 24$ & 23,16 & \multirow{4}{*}{$\frac{\leq 250}{\mathrm{~m} 5}$} \\
\hline VPN & & $n: 5$ & ms & ns & ms & \\
\hline Derigan & & $108 ?$ & 3601 & $; 787$ & 75,76 & \\
\hline VPN & & ms & ms & ms & $\mathrm{ms}$ & \\
\hline Tanp & \multirow{5}{*}{ Ittle: } & 1803 & 761 & 158 & 291 & \multirow{8}{*}{$\begin{array}{l}\therefore 75 \\
\mathrm{~ms}\end{array}$} \\
\hline VPN & & $\mathrm{nIS}$ & $\mathrm{ms}$ & ms & $\mathrm{ms}$ & \\
\hline Denigun & & 10,01 & 1,22 & 5,49 & 3.01 & \\
\hline VIN & & IIIS & $\mathbb{E s}$ & ws & 115 & \\
\hline 'Irypa & & & 0.1 & & & \\
\hline$\sqrt{2} x$ & Packer & $0.8 \%$ & $2 / 6$ & $0 \%$ & $0 \%$ & \\
\hline TDesigan & & & & & & \\
\hline VPN & Loss & $0.1 \%$ & $0 \%$ & $0 \%$ & $0 \%$ & \\
\hline
\end{tabular}

Dari tabel 4 dapat dilihat perbandingan nilai performansi VoIP tanpa VPN dan menggunakan VPN dengan bandwith yang berbeda yakni 64kbps, 128kbps, 256kbps, dan 512kbps. Dari beberapa bandwith yang dicobakan dapat disimpulkan ketika bandwith 64kbps di dapatkan nilai performansi yang lebih tinggi dari bandwith yang lain, hal ini dipengaruhi oleh codec yang digunakan. Codec G.711 mempunyai standar bitrate $64 \mathrm{kbps}$. Untuk bandwith $128 \mathrm{kbps}$ dan 256kbps delay yang didapatkan berkisar antara $30 \mathrm{~ms}$ sampai $40 \mathrm{~ms}$, jitter $4 \mathrm{~ms}$ sampai $8 \mathrm{~ms}$, dan packet loss rata-rata $0 \%$.

Selanjutnya dilakukan analisa pada pengaruh kecepatan aliran data yang disediakan bandwith. Pada pengukuran ini ada tiga variasi greed yakni low, medium dan high. Adapun hasil dari pengujian sistem dapat dilihat pada tabel 5 .
Tabel 5. Performansi VoIP menggunakan VPN dengan variasi greed

\begin{tabular}{|c|c|c|c|c|c|c|c|c|c|}
\hline \multirow{3}{*}{ 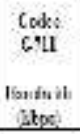 } & \multicolumn{9}{|c|}{ CBEST } \\
\hline & \multicolumn{3}{|c|}{ forr } & \multicolumn{3}{|c|}{ Hetian } & \multicolumn{3}{|c|}{ Higi. } \\
\hline & $\begin{array}{l}\text { Alby } \\
\text { Iimil }\end{array}$ & $\begin{array}{l}\text { Sim } \\
\text { (a) }\end{array}$ & $\begin{array}{l}\text { Ples } \\
\text { As: }\end{array}$ & $\begin{array}{l}\text { lobet } \\
\text { (nos) }\end{array}$ & $\begin{array}{l}\text { dim } \\
\text { (a)i }\end{array}$ & $\begin{array}{l}\text { Plate } \\
\text { Bsi }\end{array}$ & $\begin{array}{l}\text { 18h:? } \\
\text { (a: }\end{array}$ & $\begin{array}{l}\text { dillen } \\
\text { insil }\end{array}$ & $\begin{array}{l}\text { Pfuses: } \\
\text { (3) }\end{array}$ \\
\hline 64 & $11: i !$ & sas & 05 & 10893 & $16 / 5$ & $A !$ & $18 x$ & ine & 0.1 \\
\hline 123 & 61,21 & $\Leftrightarrow$ & 0,2 & 19,38 & A:A & 2,1 & 3361 & 75. & 0 \\
\hline 26 & 17.13 & $8 \pi$ & c & $1.3 \%$ & $9: 1$ & 8 & 37s: & 510 & 0 \\
\hline st: & 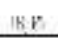 & 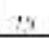 & 11 & 7917 & 19 & 0 & $28 \hat{4}$ & ial & 1 \\
\hline
\end{tabular}

Dari tabel 5 dapat dilihat bahwasanya kecepatan aliran data juga mempengaruhi nilai performansi VoIP terutama pada VPN yang membutuhkan bandwith yang lebar dengan kecepatan aliran data high. Hal ini disebabkan karena seperti yang diketahui walaupun greed dibuat high tapi kalau bandwith yang disediakan tidak cukup besar untuk menampung data, maka akan terdapat tambahan pada delay dan jitter. Sehingga dapat disimpulkan semakin walaupun aliran data dibuat high namun bandwith yang disediakan tidak cukup lebar akan sangat mempengaruhi nilai performansi VoIP pada VPN.

\section{KESIMPULAN}

Dari hasil pengukuran dan analisa performansi layanan VoIP (Voice over Internet Protocol) pada VPN (Virtual Private Network) dapat disimpulkan :

1. Pada bandwith 64 kbps dengan codec G711 layanan VoIP tanpa VPN menghasilkan nilai performansi (delay, jitter, dan packet loss) yang kurang baik, sehingga data suara yang disampaikan masih kurang jelas. Maka dari itu untuk codec G.711 pilihan bandwith $512 \mathrm{kbps}$ ke atas adalah solusi terbaik untuk mendapatkan nilai performansi yang lebih baik.

2. Penggunaan VPN mengurangi performansi VoIP. Karena nilai delay, jitter dan packet loss meningkat ketika menggunakan VPN. Bandwith 
minimal agar performansi VoIP yang menggunakan VPN mendekati performansi VoIP tanpa VPN adalah $512 \mathrm{kbps}$ pada codec G711.

3. Kecepatan aliran data (greed) juga mempengaruhi nilai performansi walaupun bandwith yang disediakan sudah cukup besar.

4. Nilai delay pada jaringan VoIP menggunakan VPN terjadi penambahan nilai delay. Hal tersebut disebabkan karena pada VPN terjadi penambahan header.

\section{SARAN}

Untuk pengembangan tugas akhir ini terdapat beberapa saran yang dapat dilakukan, seperti:

1. Menggunakan topologi jaringan yang lebih luas seperti interkoneksi pada PSTN agar dapat menimbulkan pengaruh yang besar sehingga dapat dikaji lebih dalam tentang peningkatan performansi .

2. Server VoIP yang dibuat hanya dapat melayani komunikasi suara, ke depannya diharapkan adanya penambahan layanan komunikasi seperti video call \& video conference.

3. VoIP memiliki kelemahan yaitu keamanan yang tidak terjamin. Karena berbasis IP, maka siapapun bisa melakukan penyadapan dan perekaman terhadap data VoIP. Maka dari itu kedepannya diharapkan dilakukan penelitian tentang fungsi dari VPN untuk mengamankan data VoIP tanpa mengurangi performansi dari jaringan VoIP itu sendiri.

\section{DAFTAR PUSTAKA}

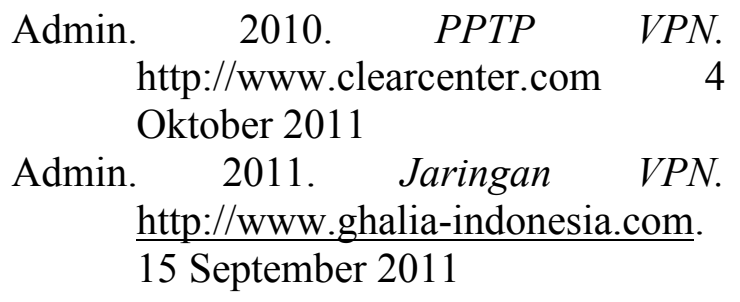

Purbo, Onno W. 2007. VoIP Cikal Bakal

“Telkom Rakyat”.Infokomputer

Raharja, Anton. 2006. VoIP Rakyat: Jaringan VoIP Berbasis Protokol SIP (Session Initiation Protocol).

Taufiq, Mochammad. 2005. Membuat SIP Extensions Pada Linux Trix Box untuk server VoIP.

www.clearos-indonesia.com, di akses tanggal 26 November 2011

D.A.Syafitri."Analisis Waktu Tunda Satu Arah Pada Panggilan VoIP Antara Jaringan UMTS Dan PSTN", 2007)

Pramudiyanto,S. "Analisa performansi realtime IP Videoconfercing Pada VPN", 2 Juli 2011) 